\title{
Total diz artroplastisi öncesi planlama
}

\section{Preoperative planning before total knee arthroplasty}

\author{
Barış Can Kuzuca ${ }^{1}$, Berk Güçlü² \\ ${ }^{1}$ Ankara Pursaklar Devlet Hastanesi, Ortopedi ve Travmatoloji Kliniği, Ankara \\ ${ }^{2}$ Ufuk Üniversitesi Dr. Rıdvan Ege Hastanesi, Ortopedi ve Travmatoloji Ana Bilim Dalı, Ankara
}

\begin{abstract}
Total diz artroplastisi (TDA), diz osteoartriti tedavisinde sıklıkla uygulanan bir cerrahi tedavidir. TDA sonrası en uygun sonuçları almak ve olası komplikasyonların önüne geçmek için hassas bir anamnez (öykü), fizik muayene süreci izlenmeli ve titiz bir hazırlık süreci uygulanmalıdır. TDA ileri yaş hastalara uygulandığı için, ilgili yaş grubunda sık görülen hastalıklar ve ilaçlar bilinmeli ve bunlara karşı gerekli tedbirler alınmalıdır. Komplikasyon beklenen durumlarda ilgili branşların uzman hekimlerine danışılmalıdır. TDA kararı verirken uygun görüntüleme yöntemleri seçilmeli ve hassasiyetle değerlendirilmelidir. Hastanın diz eklemi için en uygun artroplasti türü seçilmeli ve cerrahi öncesi hazır tutulmalıdır. Hastalara cerrahiden beklentiler ve cerrahi sonrası dönemde yapılması gereken adımlar detaylıca anlatılmalıdır. Hasta için en uygun olan anestezi yöntemine anestezi hekimi ile birlikte karar verilmelidir. Cerrahi öncesi hazırlıkta olası komplikasyonların önüne geçmek için gerekli tedbirler alınmalıdır. Enfeksiyon profilaksisi açısından hasta için uygun anti-biyoterapi ve doğru doz seçilmelidir. Cerrahi öncesi ekstremitenin hazırlığı hassaslıkla yapılmaIı ve olası enfeksiyondan korunmak için gerekli adımlar uygulanmalıdır.
\end{abstract}

Anahtar sözcükler: diz; gonartroz; total diz artroplastisi; cerrahi öncesi hazırlık
Total knee arthroplasty (TKA) is a surgical treatment that is frequently used in the treatment of knee osteoarthritis. In order to obtain the most appropriate results after TKA and to prevent possible complications, a detailed and sensitive history and physical examination process should be followed, and a meticulous preparation process should be applied. Since TKA is applied to elderly patients, common diseases and drugs in the relevant age group should be known and necessary precautions should be taken against them. In cases where complications are expected, the specialists of the relevant branches should be consulted. Appropriate imaging modalities should be selected and evaluated precisely when making a TKA decision. The most appropriate type of arthroplasty for the patient's knee joint should be selected and prepared before surgery. Expectations from surgery and the steps to be taken in the postoperative period should be explained to the patients in detail. The most appropriate anaesthesia method for the patient should be decided together with the anaesthesiologist. Necessary precautions should be taken to prevent possible complications in pre-surgical preparation. Appropriate antibiotic therapy and the dose should be selected for the patient in terms of infection prophylaxis. Preparation of the extremity before surgery should be done with precision and necessary steps should be taken to avoid possible infection.

Key words: knee; gonarthrosis; total knee arthroplasty; preoperative planning

Cerrahın sorumluluğu, bu hazırlığı başlatmak ve öncülük etmektir. ${ }^{[2]}$

Hasta cerrahi kararı verildikten sonra, hastanın cerrahi işlem için uygunluğu da değerlendirilmelidir. Bu sebeple, diz ekleminin yanında hastanın genel durumu da cerrahi öncesi mutlaka tekrar gözden geçirilmelidir. Eğer, herhangi bir ek sorun mevcut değilse, hasta mutlaka cerrahi sonrası bakım, izlem, prognoz ve komplikasyonlar açısından bilgilendirilmeli ve olası komplikasyonları önlemek için titiz bir hazırlık süreci uygulanmalıdır.

İletişim / Contact: Prof. Dr. Berk Güçlü • E-posta / E-mail: gucluberk@yahoo.com

ORCID iD: Barış Can Kuzuca, 0000-0002-3117-9037 • Berk Güçlü, 0000-0002-3705-3435

Geliş / Received: 7 Temmuz 2021 • Kabul / Accepted: 4 Ağustos 2021 


\section{ÖYKÜ ALMA (ANAMNEZ)}

Cerrahi öncesi, hasta için en uygun tedavinin total diz artroplastisi olup olmadığı tekrar değerlendirilmelidir. Total diz artroplastisi endikasyonları ve kontrendikasyonları Tablo 1'de gösterilmiştir. Hastanın ağrı ciddiyetinin ilk muayene ile değişkenlik gösterebileceği unutulmamalı ve diz eklem fonksiyonu ve eklem hareket açıklığı tekrar değerlendirilmelidir.

Cerrahi öncesi ve sonrası hasta memnuniyeti ve diz eklem fonksiyonunu değerlendirmek için çeşitli ölçeklerden yararlanılabilir. Bu amaçla 40'tan fazla değerlendirme yöntemi tanımlanmıştır. Bu yöntemler temel olarak tıbbi personel tarafindan ve hasta tarafindan olacak şekilde iki farklı şekilde uygulanabilir. Tıbbi personel tarafından uygulanan ölçeklerden en sık kullanılanı 'Hospital for Special Surgery Knee Score' (HSS Score) ve 'Knee Society Score' (KSS Score)'dur. ${ }^{[3]}$

Hasta tarafından uygulanan subjektif değerlendirmeler de hastaların beklentilerini yansıtması açısından da çok önemlidir. Western Ontario and McMaster Universities Osteoarthritis Index Score (WOMAC Score), Short Form 36 (SF-36), Oxford Knee Score, Knee Injury and Osteoarthritis Outcome Score, International Knee Documentation Committee (IKDC) Score en sık kullanılanlardır. Yapılan 860 hastalık bir çalışmada, TDA sonrası bir yıllık değerlendirmede en etkili skorların WOMAC ve SF-36 olduğu bildirilmiştir. Yüz yirmi yedi hastalık başka bir çalışmada, cerrahi öncesi WOMAC skoru 51 ve üzeri olan hastaların cerrahi sonrası WOMAC skorlarının daha yüksek olduğu bildirilmiştir. Aynı çalışmada, TDA sonrası toplam WOMAC ve WOMAC ağrı skorları ile SF-36 skorlarında belirgin iyileşme gösterilmiştir. ${ }^{[4]}$

Diz artroplastisi öncesi; omurga, iki taraflı (bilateral) kalça eklemi, diğer diz eklemi ve bilateral alt ekstremite arteriyel ve venöz yapılar mutlaka kontrol edilmelidir. Özellikle ileri yaş hastalarda, omurga patolojilerine bağıı yansıyan ağrı ve kas güçsüzlüklerinin de diz ağrısına neden olabileceği ve diz artroplastisi sonrası semptomların düzelmeyebileceği göz önünde bulundurulmalıdır. ${ }^{[3]}$

Damarsal kladikasyo da osteoartritli hastalarda aktivite azalmasına bağı olarak maskelenebilir. Eğer alt ekstremitede vasküler patoloji mevcut ise, cerrahi sonrası ağı, şişlik ve tromboz riskini artırarak dolaşım bozukluğuna neden olabilir. Bu sebeple alt ekstremite arteriyel ve venöz dolaşım muayenesi de cerrahi öncesi mutlaka yapılmalıdır. ${ }^{[5]}$

Hasta öyküsünde mutlaka kardiyopulmoner hastalıklar, diabetes mellitus (DM), endokrin hastalıklar, gastrointestinal hastalıklar, renal hastalıklar sorgulanmalıdır. TDA'da ameliyat sonrası erken dönemde kardiyopulmoner komplikasyon riski çok yüksektir. Bu sebeple ayrıntılı bir öykü ve muayene çok önemlidir. Yaşlı hastalarda DM oranı yüksek olduğu için, diyabet tipi ve kullandığı antidiyabetik ilaç mutlaka sorgulanmalıdır. Eğer hastada aydede yüzü veya genel bir ödem mevcut ise, iyatrojenik cushing sendromu mutlaka dışlanmalıdır. Tiroid patolojileri de sorgulanması gereken önemli hastalıklardandır. ${ }^{[3]}$

Enfeksiyon, TDA'nın en ciddi komplikasyonu olduğu için, cerrahi sonrası enfeksiyona neden olabilecek diş enfeksiyonları ve genitoüriner enfeksiyonlar mutlaka sorgulanmalıdır. ${ }^{[5]}$

Total diz artroplastisi öncesi geçirilmiş cerrahiler de mutlaka sorgulanmalıdır. İmkân var ise önceki cerrahileri gerçekleştiren cerrah ile görüşülmeli, yoksa ilgili bölümlere konsülte edilmeli ve artroplasti uygunluğu sorgulanmalıdır. ${ }^{6]}$

Tablo 1. TDA endikasyonları ve kontrendikasyonları ${ }^{[2]}$

\begin{tabular}{|c|c|}
\hline ENDIKASYONLAR & MUTLAK KONTRENDIKA \\
\hline Osteoartrit & Kronik diz enfeksiyonu \\
\hline Enflamatuvar artrit & Ciddi damarsal hastalıklar \\
\hline Romatoid artrit & Ekstansör mekanizma disfonks \\
\hline \multicolumn{2}{|l|}{ Osteokondromatozis } \\
\hline Villonodüler sinovit & RÖLATIF KONTRENDIKA \\
\hline Metabolik artrit & Genel kas hastalıkları \\
\hline Osteonekroz & İmmun yetmezlik \\
\hline Travma sonrası artrit & Yetersiz yumuşak doku örtüsü \\
\hline Eklem içi kırıklar & Obezite \\
\hline Ankiloz & Nöropatik artropati \\
\hline Başarısız yüksek tibial osteotomi & Osteomiyelit öyküsü \\
\hline
\end{tabular}




\section{FiZiK MUAYENE}

ilk olarak hastanın cildi kontrol edilmelidir. Cildin elastikiyeti, yara iyileşmesi ve cerrahi sonrası rehabilitasyon için fikir vericidir. Eğer diz ekleminde cerrahi nedbe (skar) dokusu mevcut ise, yeri ve yapışıklık (adhezyon) durumu değerlendirilmelidir. Ek olarak hassasiyet, ısı artışı, eklem şişliği de değerlendirilmeli ve olası efüzyon varlığında etiyolojisi aydınlatılmalıdır. Patella kompresyon testi uygulanarak patellar eklem yüzeyinin değişime ihtiyacı olup olmadığı kontrol edilebilir. Deformitenin çeşidi ve derecesine göre kullanılacak olan cerrahi yöntem ve implant belirlenmelidir. Fleksiyon ve ekstansiyon dereceleri cerrahi öncesi belirlenmelidir. Aktif ve pasif eklem hareket açıklıkları mutlaka gonyometre ile ölçülmelidir. Kontraktür mevcut ise not edilmelidir. Cerrahi öncesi kuadriseps ve hamstring kas güçleri mutlaka ölçülmelidir. Diz ekleminin olası instabilitesi de cerrahi öncesi mutlaka değerlendirilmelidir. Mediolateral ve anteroposterior instabilite mevcut ise fizik muayene ve stres grafileri ile değerlendirilmelidir. ${ }^{[5]}$

Diz eklem muayenesinden sonra kalça ve omurga muayenesi yapılmalıdır. Ek olarak dolaşım sistemi muayenesi mutlaka yapılmalı ve zayıf nabız, cilt ülserleri, parmak nekrozları durumunda vasküler patoloji varlığı mutlaka göz önünde bulundurulmalıdır. ${ }^{[3]}$

\section{CERRAHI ÖNCESI DEĞERLENDIRME}

Ameliyat öncesi değerlendirme iki bölüme ayrılabilir; genel hasta kontrolü ve diz ekleminin kontrolü. Genel hasta kontrolü temel bir muayenedir ve geçmiş tıbbi öyküde bulunan anormalliklerin daha ayrıntıIı olarak çalışılması gerekir. Örneğin, hipertansiyon varlığında EKG'de anormal bulgular da eşlik ediyor ise, ekokardiyogram veya talyum taraması gerekli olabilir. DM, endokrin hastalıklar veya sinir sistemi ile ilgili anomaliler varlığında ilgili uzmanlık alanına danışılmalıdır. Osteoporoz durumunda, kemik mineral dansitometresi uygulanabilir ve gerekli ise ameliyat sonrası tedavi başlanabilir. Tromboz öyküsü olan veya tromboz açısından yüksek riskli olan hastalarda venografi de yapılabilir. Periferik nabızlarda zayıflık var ise veya diz grafisinde popliteal arter - ven hizasında yoğun kalsifikasyonlar gözlenmiş ise Doppler testi yapılabilir ve gerekirse periferik anjiyografi ile desteklenmelidir. ${ }^{[6]}$

Diz eklemini değerlendirmek için direkt grafi ilk istenecek tetkiktir. En sık kullanılan grafiler yük vererek çekilen ön-arka (antero-posterior, AP) ve yan (lateral) grafilerdir. Diz ekleminin durumuna göre stres grafileri, patellofemoral grafiler (Merchant grafisi, patella sunrise grafisi) ve rotasyonel grafiler alınabilir. Koronal düzlemde tibiofemoral açı değerlendirilmesi için alt ekstremite uzunluk grafisi istenmeli ve değerlendirilmelidir. İleri deformite, ileri fleksiyon kontraktürü, instabilite, kemik defekti gibi durumlarda farklı tip proteze ihtiyaç duyulabilir ve cerrah bunu öngörerek cerrahi öncesi önlemini almalıdır. ${ }^{[3]}$

\section{Antero-Posterior Grafi}

Bu grafi sırtüstü (supin) pozisyonda veya ayakta uygulanabilir. Ancak TDA öncesi değerlendirmede yük vererek uygulanan grafi daha değerlidir (Şekil 1a). Yük vererek çekilen AP grafilerde eklem aralığı daha iyi değerlendirilir. Eşlik eden osteofitler ve subkondral kemik değişiklikleri de görülebilir. ${ }^{[1]}$

\section{Lateral Grafi}

Lateral grafi, diz $30^{\circ}$ fleksiyonda çekilir (Şekil 1b). Bu grafi sayesinde patellar yükseklik, serbest cisimler ve TDA'da temizlenmez ise tibial inserti sıkıştırabilecek posterior osteofitleri gösterebilir. Yine lateral grafi sayesinde patellar yükseklik Insall-Salvati indeksi ile değerlendirilebilir. Insall-Salvati indeksi, lateral grafide patella yüksekliğinin patellar tendon yüksekliğine oranı ile hesaplanır ve $0,8-1,2$ arası normal olarak değerlendirilir; 1,2 üzeri oranlar 'patella alta', 0,8 altı oranlar 'patella baja' olarak tanımlanır. Modifiye Insall-Salvati indeksi, Caton-Deschamps indeksi, Blackburne-Peel oranı ve Blummensaat hattı da patella yüksekliğini değerlendirmek için kullanılan diğer oranlardır. ${ }^{[1]}$

\section{Ekstremite Uzunluk Grafisi}

Ekstremite uzunluk grafisi, tüm alt ekstremitenin (kalça - ayak bileği arası) nötral rotasyonda görüntülenmesini içerir (Şekil 1c). Bu grafinin amacı, TDA'da uygun mekanik aksı ve eklem çizgisini sağlamaktır. ${ }^{[1]}$

\section{Merchant Grafisi}

Patellanın pozisyonu ve femura göre konumu en iyi bu grafide değerlendirilir. Hasta supin pozisyonda ve $\operatorname{diz} 45^{\circ}$ fleksiyonda iken çekilir (Şekil 1d). Bu grafi sayesinde cerrah patellar tilt ve patellofemoral artrit olup olmadığını değerlendirebilir ve TDA esnasında patellanın değiştirilmesine karar verebilir. ${ }^{[1]}$

\section{Tünel Grafisi}

Hasta yüzüstü pozisyonda iken diz $40^{\circ}$ fleksiyonda iken çekilir. Femur medial ve lateral kondillerin postero-superior eklem yüzlerini ve interkondiler notch'u göstermesi açısından değerlidir. Özellikle genç hastalarda osteokondritis dissekans ve eklem içi serbest cisimleri göstermede değerlidir. ${ }^{[1]}$ 

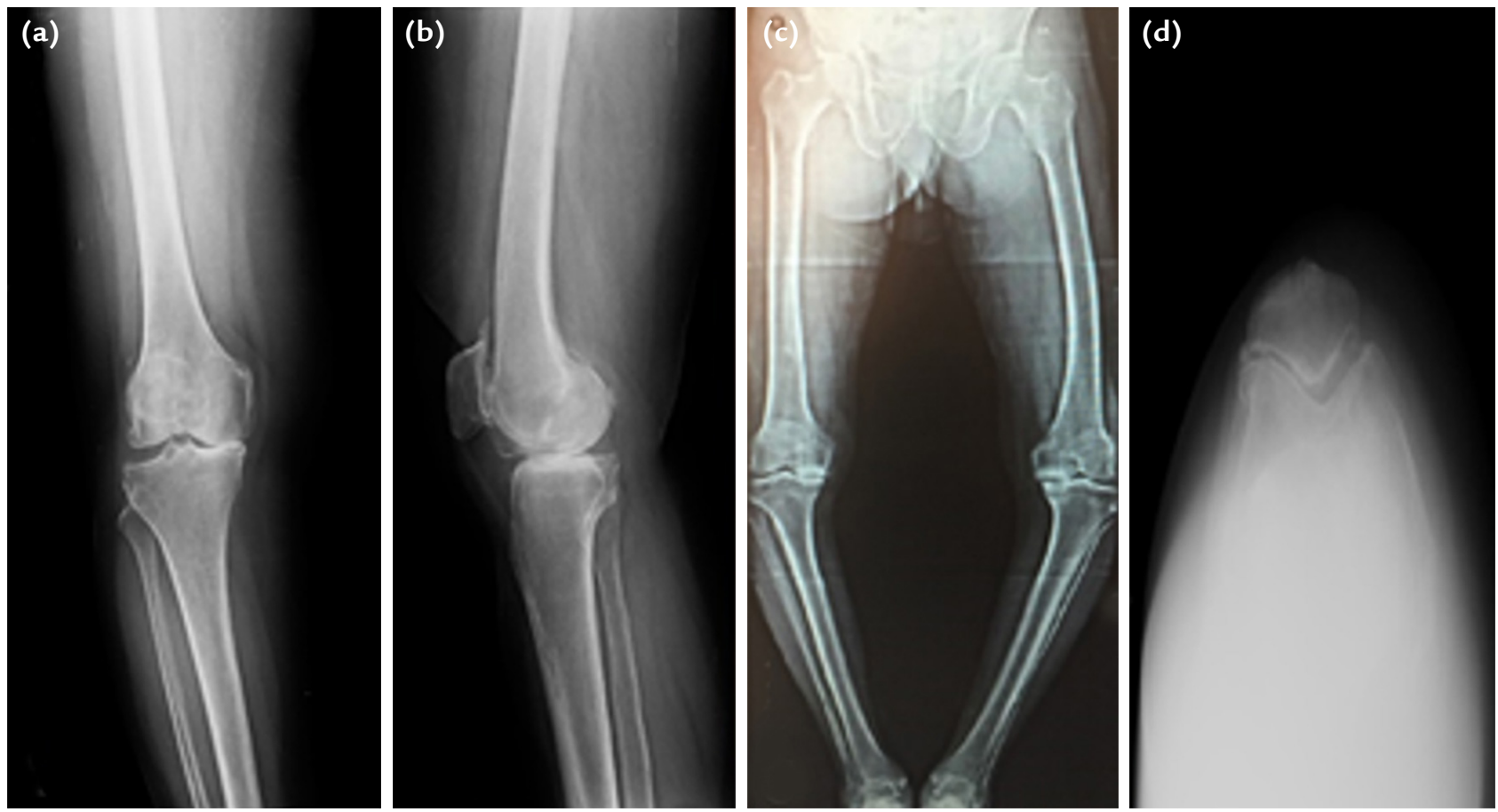

Şekil 1. a-d. TDA öncesi yük vererek çekilen AP (a), lateral (b), ekstremite uzunluk (c) ve Merchant (d) grafileri.

Günümüz teknolojik gelişmeleri sayesinde, dijital ortamda çekilen grafiler üzerinden şablonlama yapmak mümkün hale gelmiştir (Şekil 2). Bu sayede cerrahi öncesi daha hassas planlama yapılarak ameliyat sırasında komplikasyon ile karşılaşma riski azalmıştır. ${ }^{[6]}$

Grafilere ek olarak, özellikli hastalarda bilgisayarlı tomografi (BT) veya manyetik rezonans (MR) görüntüleme istenebilir. Üç boyutlu BT sayesinde, cerrahi öncesi şablonlama yapmak ve robotik cerrahi ile uygun kesileri ayarlamak da mümkün hale gelmiştir (Şekil 3). Diz MR'si, osteoartrit dışı diz patolojilerini değerlendirmek için tercih edilmektedir. Bu nedenle, artroplasti uygulanması planlanan hastalarda önerilmemektedir. Rutin kontrolde enflamatuvar artritten şüphelenilirse eklem aspirasyonu ve lökosit işaretli kemik taraması uygulanabilir. ${ }^{[5]}$

Total diz artroplastisinin yapılmasına karar verildikten sonra, bir diğer değerlendirme de tek aşamalı bilateral veya iki aşamalı unilateral olarak yapılmasına karar vermek olmalıdır. Bu karar genellikle hazırık öncesi verilir, ancak ameliyat öncesi kontrol sonuçları kararı değiştirebilir. Tek aşamalı TDP, maliyet etkindir ve rehabilitasyon süresini kısaltır. Ancak, tek aşamalı cerrahide komplikasyon riski daha yüksektir. Bu nedenle hastanın yaşı, genel durumu ve diz ekleminin durumu dikkate alınmalıdır. Öte yandan, iki aşamalı ameliyat

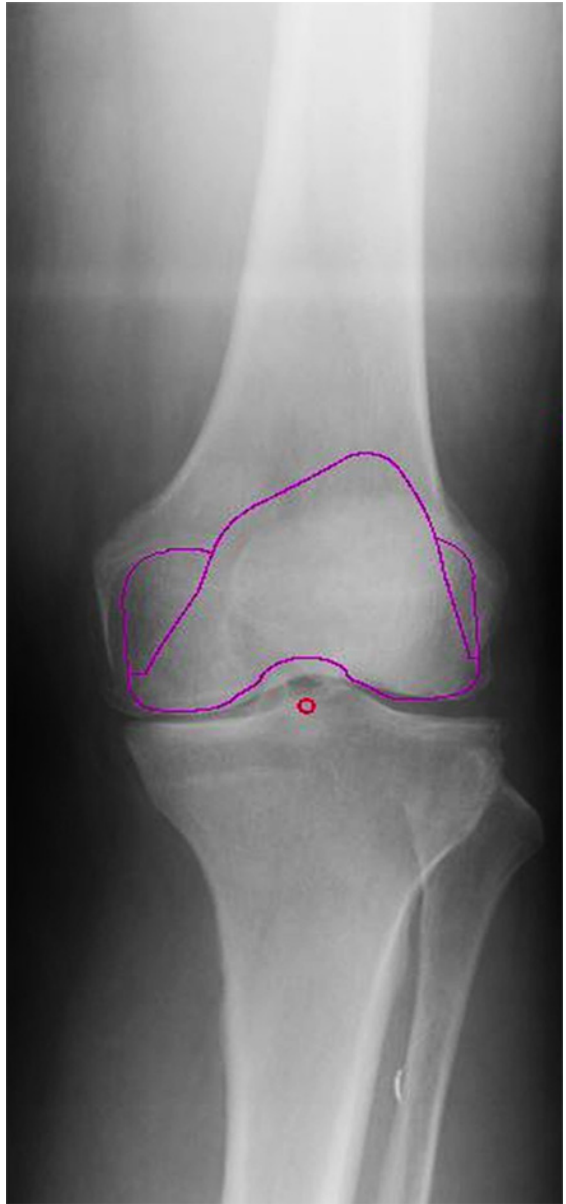

Şekil 2. Dijital AP grafi üzerinden şablonlama. 


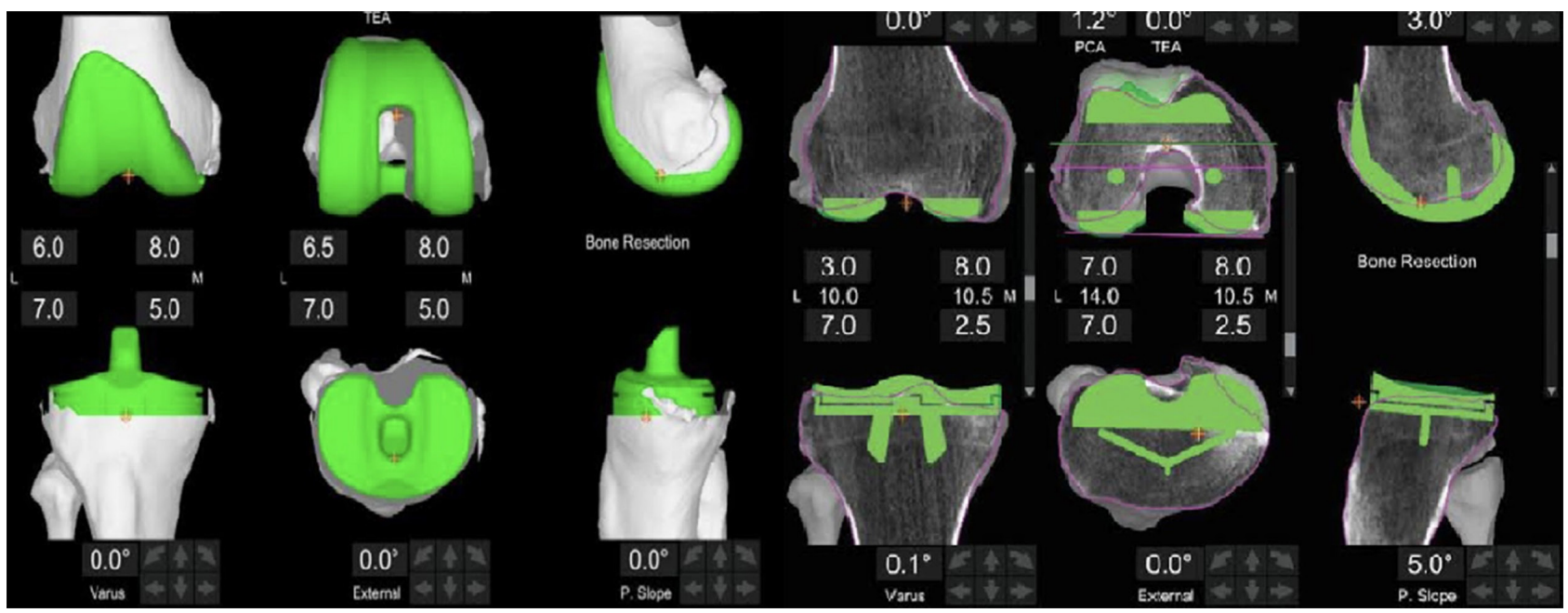

Şekil 3. Üç boyutlu BT kullanılarak robotik cerrahi esnasında şablonlama.

hastane süresini uzatır. Bazı özel durumlarda iki ayrı cerrahi ekip tarafindan aynı seansta iki diz ameliyat edilebilir. Böylece anestezi süresi oldukça azaltılabilir, ancak kalbin hemodinamik olarak aşırı yüklenmesi ve yüksek enfeksiyon riski söz konusudur. Bu nedenle, bu operasyonun sadece çok istisnai durumlarda ve özelleşmiş merkezlerde uygulanması tavsiye edilir. ${ }^{[3]}$

Genel olarak, tek aşamalı ve iki aşamalı TDP sonuçlarının farklı olmadığı kabul edilmektedir. Bu konu üzerindeki en büyük tartışma komplikasyonların görülme sıklığıdır. Tek aşamalı cerrahide süre uzunluğu, daha fazla kanama görüldügü için genellikle daha büyük risklere sahip olduğu düşünülmektedir. Bu nedenle daha yüksek transfüzyon ihtiyacı, konjestif kalp yetmezliği insidansı geliştiği bildirilmiştir. Ayrıca akut deliryum ve yağ embolisi riski de artmaktadır. Yapılan bir çalışmada, iki taraflı (bilateral) uygulanan TDA'da 70 yaş ve üzeri hastalarda kardiyak komplikasyonların daha fazla olduğu bildirilmiştir. ${ }^{[7]}$ Seksen yaş ve üzerinde bilateral TDA uygulanan 98 hastalık başka bir çalışmada, kardiyovasküler komplikasyonların bilateral hastalarda $\% 22$, unilateral hastalarda $\% 6$ olarak bildirilmiştir. ${ }^{[8]} 27.807$ hasta içeren 18 makalelik bir meta-analizde pulmoner emboli, kardiyovasküler komplikasyonlar ve mortalite bilateral TDA uygulanan hastalarda daha fazla görülmüştür. ${ }^{[9]}$

Cerrahi sonrası hasta eğitimi hasta memnuniyetini artırır. En etkili hasta eğitimi cerrahi öncesi yapılabilir. Cerrahiden hemen sonra, hastalar tam olarak bilinçli değildir ve talimatlara dikkat etmeyebilir. Ameliyat öncesi, hastalar artroplastinin hedefi, ameliyat sonrası ilerleme, cerrahi sonrası rehabilitasyon ve olası erken komplikasyonlarla ilgili bilgi sahibi olmalıdır. TDA'nın amacının, hastanın ağrısız yürümesi olduğu, gündelik işlerini yapabileceği ve minimal sportif aktiviteler olacağı belirtilmelidir. Gerçekçi olmayan beklentilerle hasta memnuniyeti azalabilir. Protez implantının ömrünün olduğu ve normal bir diz fonksiyonu elde edilememe riski mutlaka vurgulanmalıdır. ${ }^{[6]}$

\section{CERRAHI IÇIN SON KONTROL}

Cerrahi için son kontrol; hastanın cerrahi için onayı, tıbbi hazırlık, anestezi hazırlığı ve cerrahi bölgenin hazırlığından oluşur.

\section{Onam Formu}

Cerrahi öncesi hastalardan veya hasta yakınlarından aydınlatılmış onam formuna izin almak zorunludur. Aydınlatılmış onam formunda cerrahinin amacı, cerrahinin yönü, cerrahi esnasında yapılacak uygulamalar, eğer ihtimal dâhilinde ise yapılması öngörülen ek uygulamalar ve olası komplikasyonlar belirtilmeli ve hasta bilgilendirilmelidir. Hastalar bu forma isimlerini yazmalı ve onay formuna imza atmalıdır. Gerekli durumlarda, bir video kamera ile de ifade kayıt altına alınabilir. Ayrıca cerrahi öncesi hastanın taraf işaretlenmesi de yapılmalıdır. ${ }^{[3]}$

\section{Tıbbi Hazırlık}

Hipertansiyon ve DM gibi genel sorunlar anestezi uzmanının talimatlarına göre optimize edilmelidir. Hastalarda hipertansiyon varlığında, diyastolik basınç $95 \mathrm{mmHg}$ 'dan sistolik basınç ise $160 \mathrm{mmHg}$ 'dan düşük olması istenir ve kan basıncı 180/110 mm Hg'den fazla olmamalıdır. Ancak, kan basıncında kısa sürede 
çok sert azalmalar kardiyovasküler ve serebrovasküler sistemler için riskli olabilir. ${ }^{[5]}$

Diabetes mellitus hastalarında ise kan şekeri cerrahi öncesi 200 mg/dl'den düşük olmalıdır. Alttmış altı çalışmada 500.000 üzeri hasta içeren bir meta-analizde, DM hastalarında yüzeyel ve derin yara yeri enfeksiyon riski \%3,4 iken olmayanlarda \%0,87 olarak bildirilmiştir. ${ }^{[10]}$ Yapılan başka çalışmalarda ise DM kontrol altında değil ise, üriner enfeksiyon, pnömoni ve inme riski ile beraber cerrahi sonrası gerekli transfüzyon miktarı da artmaktadır. ${ }^{[11,12]}$ Bu sebeple, yapılan çalışmalarda, DM hastalarının HbA1C seviyelerinin \%6,5-7'den düşük olması tavsiye edilmektedir. ${ }^{[10]}$

Cushing sendromu veya tiroid disfonksiyonu gibi endokrin hastalıkları olan hastaların yönetiminde cerrahi öncesi mutlaka bir endokrinoloji ve metabolizma hastalıkları uzmanının görüşü alınmalıdır.

Cerrahi öncesi soğuk algınlığı benzeri viral semptomları olan hastaların ameliyatlarının ertelenmesi tavsiye edilir. Cerrahi öncesi non-steroidal anti-inflamatuvar (NSAi) ilaçların kesilmesi konusunda da bazı tartışmalar mevcuttur. Asetil-salisilik-asit dışı NSAi ilaçlar, geri-dönüşümlü olarak plateletlerin agregasyonlarını inhibe etmektedir. Bu sebeple hastaların kanama zamanlarını uzatabilir. Genel yaklaşım, cerrahi öncesi NSAi ilaçların bir hafta süre ile kesilmesidir. Fakat, yakın zamanda yapılan araştırmalarda, kesilmenin gerekli olmadığını belirten literatür de mevcuttur. Pre-emptif ağrı kontrolü görüşüne ise de cerrrahi öncesi NSAi ilaçlar uygulanmalıdır. ${ }^{[3]}$

Cerrahi öncesi warfarin tedavisi de durdurulmalıdır. Ancak yapılan bir çalışmada, warfarin kullanımının cerrahi sonrası transfüzyon ihtiyacı, yara problemi ve revizyon gereksinimi ile ilgili herhangi bir etkisi saptanmamıştır. ${ }^{[13]}$

\section{Anesteziye Hazırlık}

Anestezi yöntemi konusunda son karar anestezi uzmanı tarafından verilse de, hastaya anestezi yöntemini seçme konusunda imkân tanınmalıdır. Genellikle TDA için, genel anestezi, spinal anestezi, epidural anestezi veya periferik sinir bloğu tercih edilmektedir. Cerrahi sonrası ağrıyı azaltmak için birden fazla tür birlikte kullanılabilir.

Hastalarda romatoid artrit veya birden fazla eklemde ankiloz mevcut ise, entübasyon ihtimali açısından servikal omurganın durumunu kontrol etmek için servikal vertebra grafisi çekilmelidir. Spinal anestezi öncesi de lomber vertebra grafileri yararlı olabilir. ${ }^{[1]}$

Genel anestezi yüksek başarı oranı ve zaman tasarrufu sağlamasına rağmen cerrahi sonrası ağrı, bulantı ve kusmaya neden olabilir. Spinal veya epidural anestezinin düşük morbidite oranı, düşük tromboz riski ve ameliyat sonrası düşük ağrı sağlamasına rağmen, sempatik blok nedeniyle hipotansiyon, bradikardi, idrar retansiyonu, dural ponksiyona bağlı postüral baş ağrısı, spinal hematom ve epidural apse riskleri bildirilmiştir. ${ }^{[3]}$

Periferik sinir bloğu bölgesel bir anestezi yöntemidir ve ameliyat sonrası yüksek hasta memnuniyeti ve erken ambulasyon sağlamaktadır. Buna rağmen, periferik sinir bloğu, yüksek lokal anestezik ihtiyacı nedeni ile bilateral TDA'da nadiren kullanılır. Cerrahi sırasında yeterli analjeziyi sağlamakta zorlanma nedeni ile de sıklıkla genel anesteziye ihtiyaç duyulur. Yedi yüz dokuz TDA uygulamasını içeren bir çalışmada, periferik sinir bloğu sonrası 12 olguda cerrahi sonrası düşme ve buna bağlı üç revizyon ihtiyacı, beş femoral nörit ve bir yeni atriyal fibrilasyon olgusu bildirilmiş ve femoral sinir bloğunun beklendiği kadar etkili bir yöntem olmadığı görüşüne varılmıştır. ${ }^{[14]}$ Diğer taraftan 28 çalışmalık ve 1.538 hastalık bir meta-analizde, periferik sinir bloğu uygulanan hastalarda genel anesteziye kıyasla mortalite ve kardiyovasküler morbidite açısından herhangi bir fark tespit edilmemiştir ve cerrahi sonrası rehabilitasyon açısından genel anesteziden daha üstün olduğu bildirilmiştir. ${ }^{[15]}$

Cerrahi öncesi mutlaka damar yolu hazırlanmalı ve idrar sondası takılmalıdır. Kan kaybı beklenen bir cerrahi olmamasına rağmen, cerrahi öncesi iki ünite kan hazırlığı yapılmış olmalıdır. Kan ürünü genellikle anestezi uzmanı tarafından seçilmektedir, ancak genellikle eritrosit süspansiyonu tercih edilmektedir.

Cerrahi öncesi olası enfeksiyonu engellemek için profilaktik antibiyoterapi rutin bir uygulamadır. Optimal profilaktik antibiyotik en sık görülen etkenlere karşı bakterisidal olmalıdır. Uygun dağılım oranı ve maliyet etkinliği nedeni ile genellikle operasyondan 1-2 saat öncesinde intravenöz (i.v.) 1. veya 2 . kuşak sefalosprorin (sefazolin/sefuroksim) tercih edilmektedir. ${ }^{[1]}$ Daha düşük spektrumu olmasına rağmen, beta-laktam alerjisi durumunda klindamisin veya glikopeptit grubu antibiyotikler (vankomisin/teikoplanin) de tercih edilebilir. Yapılan bir çalışmada, profilaktik antibiyoterapide vankomisinin sefalosporinlere üstünlüğü olmadığı ve yan etki sıklığının daha fazla olduğu gösterilmiştir. ${ }^{[16]}$

Uygulanacak antibiyoterapinin doz ayarlaması da hasta kilosuna göre düzenlenmelidir. Antibiyoterapinin etkinliği için vücutta belirli bir konsantrasyonun üzerinde olmalıdır ve obez hastalarda dağılım yetersiz olacaktır. Güncel literatürde, 120 kilo ve üzeri hastalarda sefalosporinin 3 gram olarak uygulanması önerilmektedir. ${ }^{[17]}$ 


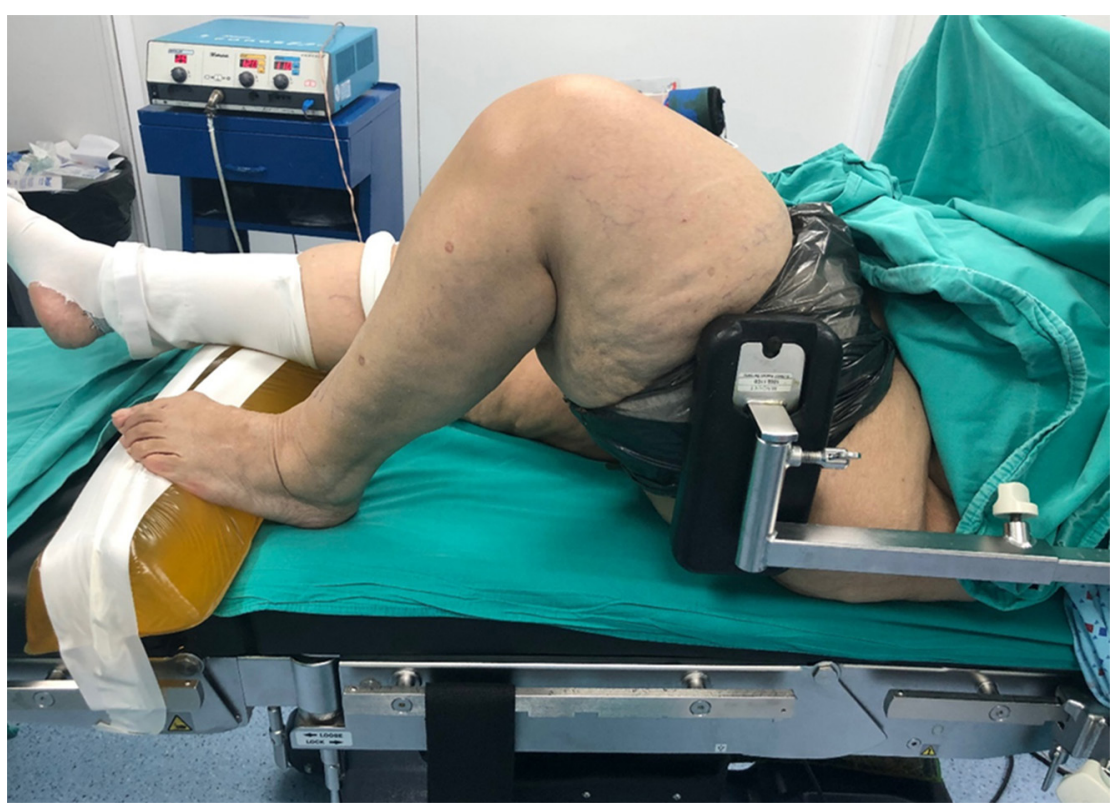

Şekil 4. Obez hastada TDA öncesi hazırlık ve turnike uygulanması.

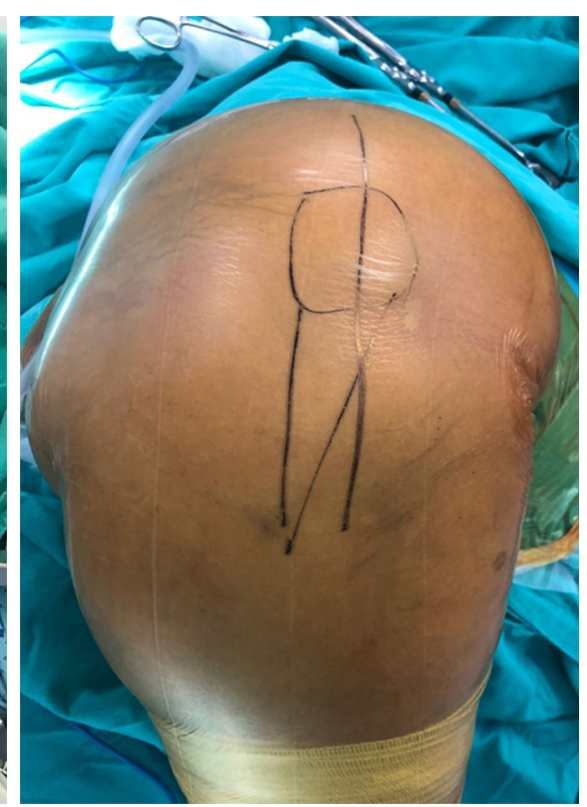

Şekil 5. TDA öncesi iyot-emdirilmiş drape uygulanması.

\section{Diz Eklemi Hazırlığı}

Operasyon bölgesinin hazırlanması için, cerrahi alan uygun bir şekilde temizlenmelidir. Yedi yüz hastalık ileriye dönük bir çalışmada, ameliyat sırasında kültür pozitifliği; klorheksidin ile temizlik sonrası $\% 4$, povidon-iyot sonrası $\% 9$ ve sabun sonrası $\% 14$ olarak bildirilmiştir. ${ }^{[18]}$ Epilasyon, tıraş veya kimyasallar ile yapılabilir. Tıraşlamanın yararı olup olmadığı tartışmalıdır. Tıraş enfeksiyon oranını büyük ölçüde azaltmaz ancak, tıraş esnasında ciltte yaralanma olursa enfeksiyon riskini artırabilir. On dört randomize kontrollü çalışma içeren bir meta-analizde, elektronik cihazlar veya kremler ile uygulanan tıraşlar sonrası enfeksiyon riskinin jilete kıyasla daha düşük olduğu bildirilmiştir. ${ }^{[19]}$

Total diz artroplastisi esnasında turnike uygulanması uzun süredir standart bir prosedür olarak kabul edilmektedir (Şekil 4). Fakat son zamanlarda, turnike uygulamasının iskemik hasar oluşturduğu hususunda çekinceler mevcuttur. Elli iki hastalık bir çalışmada, obez hastalarda turnike bölgesinde yara oluşturduğu ve enfeksiyon riskini artırdığı gösterilmiştir. ${ }^{[20]}$ Elli hastalık başka bir randomize bir kontrollü çalışmada ise, turnike uygulamasının kan kaybı açısından bir etkisi olmadığı gösterilmiştir. [21]

Cerrahi bölgesi için drape uygulaması, bariyer oluşturarak enfeksiyon riskini azaltmaktadır. Yapılan çalışmalarda, iyot emdirilmiş drape uygulamasının en etkili yöntem olduğu gösterilmiştir (Şekil 5). ${ }^{[22]}$

\section{KAYNAKLAR}

1. Comitini S, Tigani D, Commessatti M. Preoperative Planning in Total Knee Arthroplasty (TKA). In: Affatato S, editor. Surgical Techniques in Total Knee Arthroplasty and Alternative Procedures, 1st ed. Elsevier, US: Woodhead Publishing; 2014.

2. Cho W. Knee Joint Arthroplasty, Section 2: Implant Selection. Berlin Heidelberg: Springer-Verlag; 2014. p.13-65. Crossref

3. Barrack RL, Booth RE, Lonner JH. Orthopaedic Knowledge Update 3 Hip and Knee Reconstruction, Section 2. Rosemont, Illionis: American Academy of Orthopaedic Surgeons; 2006. p.187-311.

4. Lavernia C, D’apuzzo M, Rossi MD, Lee D. Is Postoperative Function After Hip or Knee Arthroplasty Influenced by Preoperative Functional Levels? J Arthroplasty 2009;24(7):1033-43. Crossref

5. Scott WN, Clarke HD, Cushner FD. Insall and Scott Surgery of the Knee Fourth Edition, Volume 1, Section 2, Chapter 6. Churchill Livingstone Elsevier; 2006. p.145-92.

6. Canale ST, Beaty J. Campbell's Operative Orthopaedics 12th ed. Volume 1, Section 3, Part 7. Netherlands: Elsevier; 2013. p.376-444.

7. Bullock DP, Sporer SM, Shirreffs TG. Comparison of Simultaneous Bilateral with Unilateral Total Knee Arthroplasty in terms of Perioperative Complications. J Bone Joint Surg Am 2003;85-A(10):1981-6. Crossref

8. Lynch NM, Trousdale RT, Ilstrup DM. Complications After Concomitant Bilateral Total Knee Arthroplasty in Elderly Patients. Mayo Clin Proc 1997;72(9):799-805. Crossref

9. Restrepo C, Parvizi J, Dietrich T, Einhorn TA. Safety of Simultaneous Bilateral Total Knee Arthroplasty: a MetaAnalysis. J Bone Joint Surg Am 2007;89(6):1220-6. Crossref

10. Rudy MD, Ahuja NK, Aaronson AJ. Diabetes and Hyperglycemia in Lower-Extremity Total Joint Arthroplasty. Clinical Epidemiology, Outcomes, and Management. JBJS Reviews 2018;6(5):e10. Crossref 
11. Marchant $M H$, Viens NA, Cook C, Vail TP, Bolognesi MP. The Impact of Glycemic Control and Diabetes Mellitus on Perioperative Outcomes After Total Joint Arthroplasty. J Bone Joint Surg Am 2009;91(7):1621-9. Crossref

12. Bolognesi MP, Marchant M Jr, Viens NA, Cook C, Pietrobon $\mathrm{R}$, Vail TP. The Impact of Diabetes on Perioperative Patient Outcomes After Total Hip and Total Knee Arthroplasty in the United States. J Arthroplasty 2008;23(2):322-3. Crossref

13. Rhodes DA, Severson EP, Hodrick JT, Dunn HK, Hofmann AA. Discontinuation of Warfarin Is Unnecessary in Total Knee Arthroplasty. Clin Orthop Relat Res 2010;468(1):120-6. Crossref

14. Sharma S, lorio R, Specht LM, Lepie SD, Healy WL. Complications of Femoral Nerve Block for Total Knee Arthroplasty. Clin Orthop Relat Res 2010;468(1):135-40. Crossref

15. Macfarlane AJ, Prasad GA, Chan WWS, Brull R. Does regional anesthesia improve outcome after total knee arthroplasty? Clin Orthop Relat Res 2009;467(9):2379-402. Crossref

16. Courtney PM, Melnic CM, Zimmer Z, Anari J, Lee G-C. Addition of Vancomycin to Cefazolin Prophylaxis is Associated with Acute Kidney Injury After Primary Joint Arthroplasty. Clin Orthop Relat Res 2015;473(7):2197203. Crossref
17. Bratzler DW, Dellinger EP, Olsen KM, Perl TM, Auwaerter PG, Bolon MK, Fish DN, Napolitano LM, Sawyer RG, Slain D, Steinberg JP, Weinstein RA; American Society of HealthSystem Pharmacists (ASHP); Infectious Diseases Society of America (IDSA); Surgical Infection Society (SIS); Society for Healthcare Epidemiology of America (SHEA). Clinical Practice Guidelines for Antimicrobial Prophylaxis in Surgery. Surg Infect (Larchmt) 2013;14(1):73-156. Crossref

18. Garibaldi RA. Prevention of Intraoperative Wound Contamination with Chlorhexidine Shower and Scrub. J Hosp Infect 1988;11 Suppl B:5-9. Crossref

19. Tanner J, Norrie P, Melen K. Preoperative hair removal to reduce surgical site infection. Cochrane Database Syst Rev 2011;11:CD004122. Crossref

20. Liu P-L, Li D-Q, YK Zhang, Lu Q-S, Ma L, Bao X-Z, Zhang M. Effects of Unilateral Tourniquet Used in Patients Undergoing Simultaneous Bilateral Total Knee Arthroplasty. Orthop Surg 2017;9(2):180-5. Crossref

21. Ledin H, Aspenberg P, Good L. Tourniquet Use in Total Knee Replacement does not improve Fixation, but Appears to Reduce Final Range of Motion. Acta Orthop 2012;83(5):499503. Crossref

22. Webster J, Alghamdi A. Use of Plastic Adhesive Drapes During Surgery for Preventing Surgical Site Infection. Cochrane Database Syst Rev 2015:CD006353. Crossref 